Supplement of Biogeosciences Discuss., 12, 6215-6284, 2015

http://www.biogeosciences-discuss.net/12/6215/2015/

doi:10.5194/bgd-12-6215-2015-supplement

(C) Author(s) 2015. CC Attribution 3.0 License.

(c) (1)

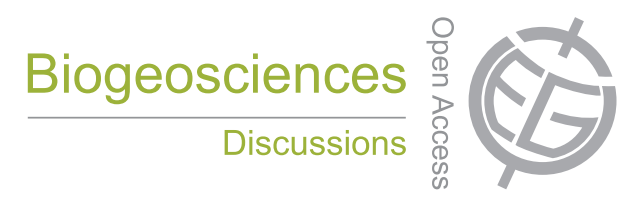

Supplement of

\title{
Co-variation of metabolic rates and cell-size in coccolithophores
}

G. Aloisi

Correspondence to: G. Aloisi (galod@locean-ipsl.upmc.fr) 


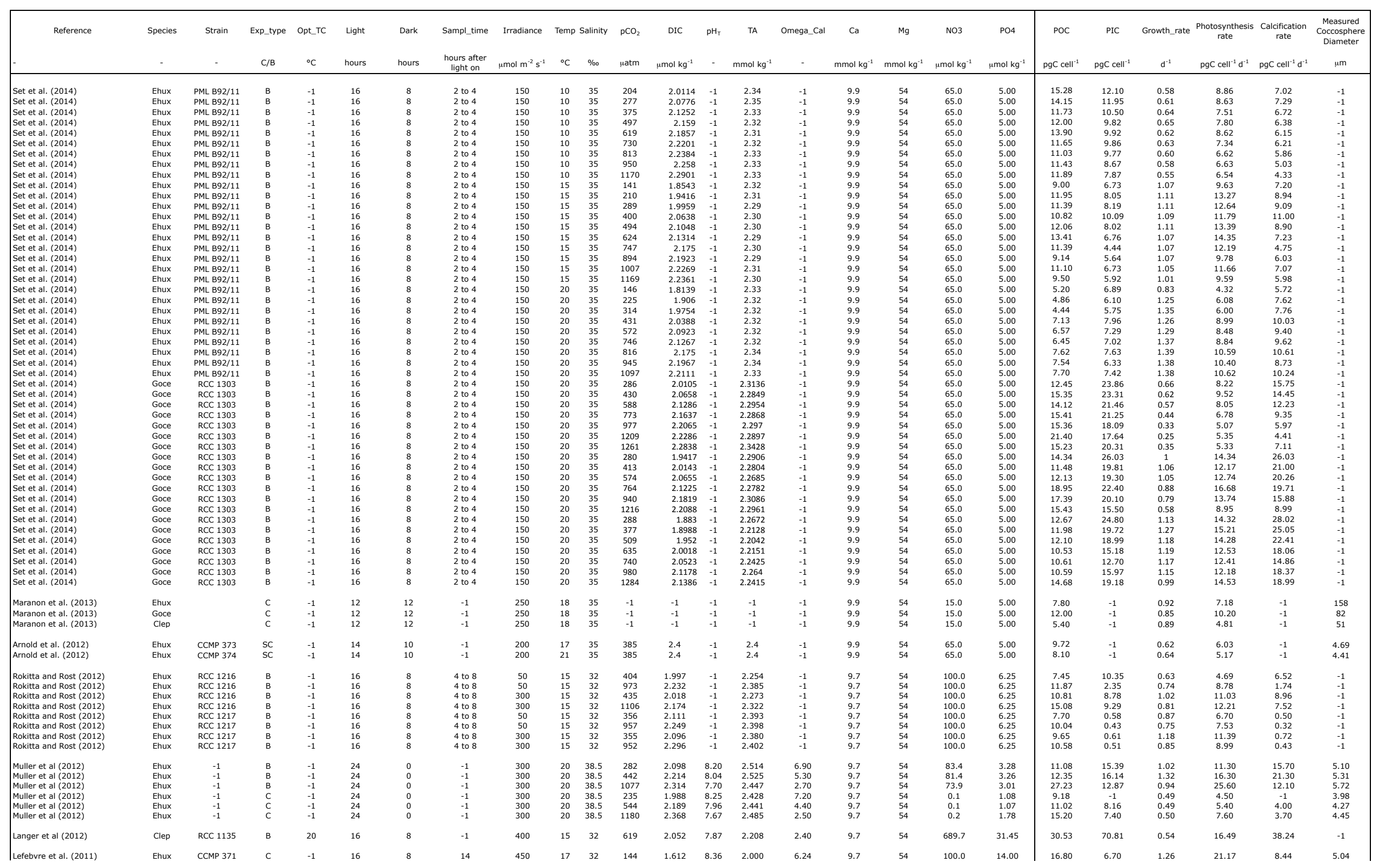




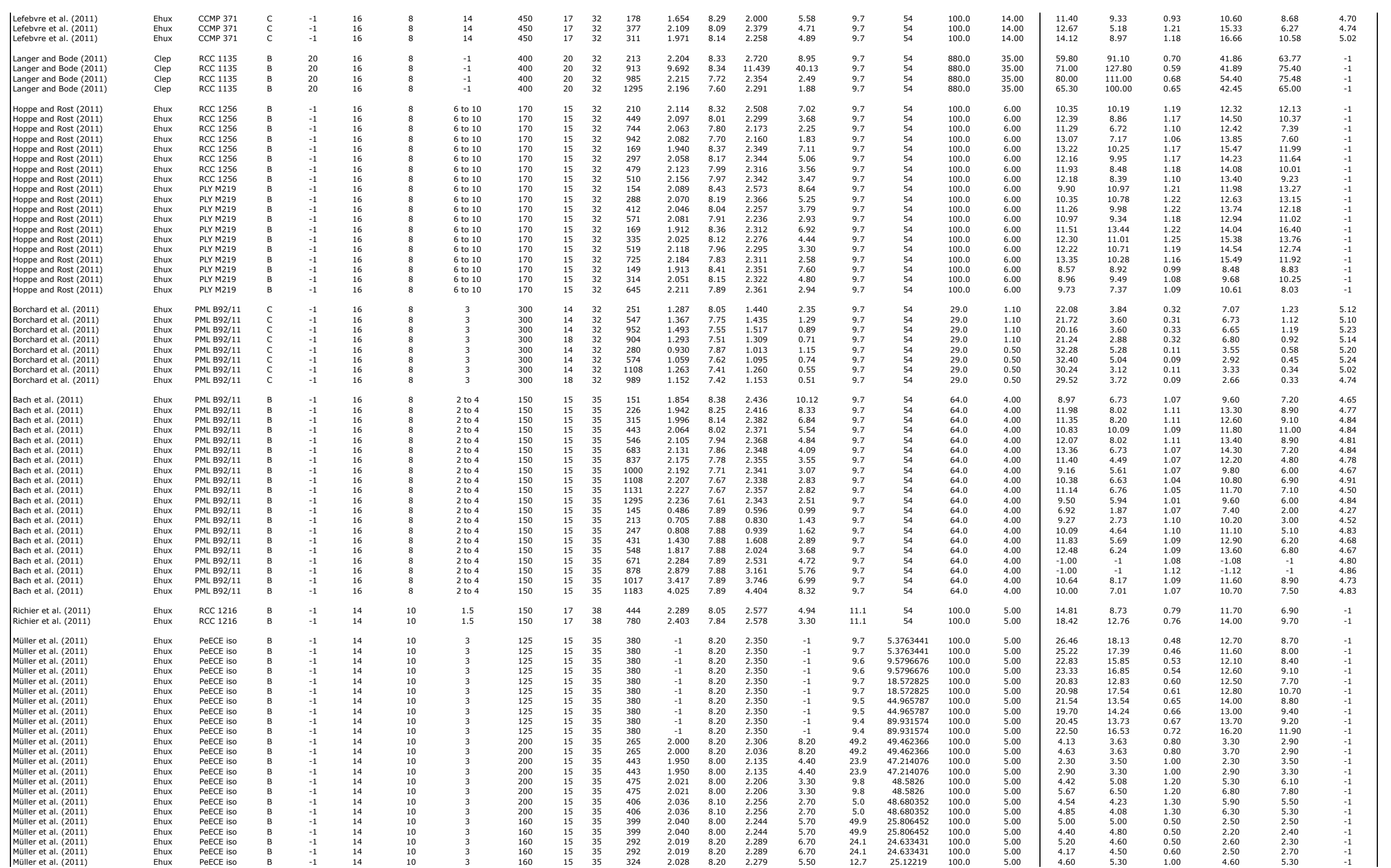




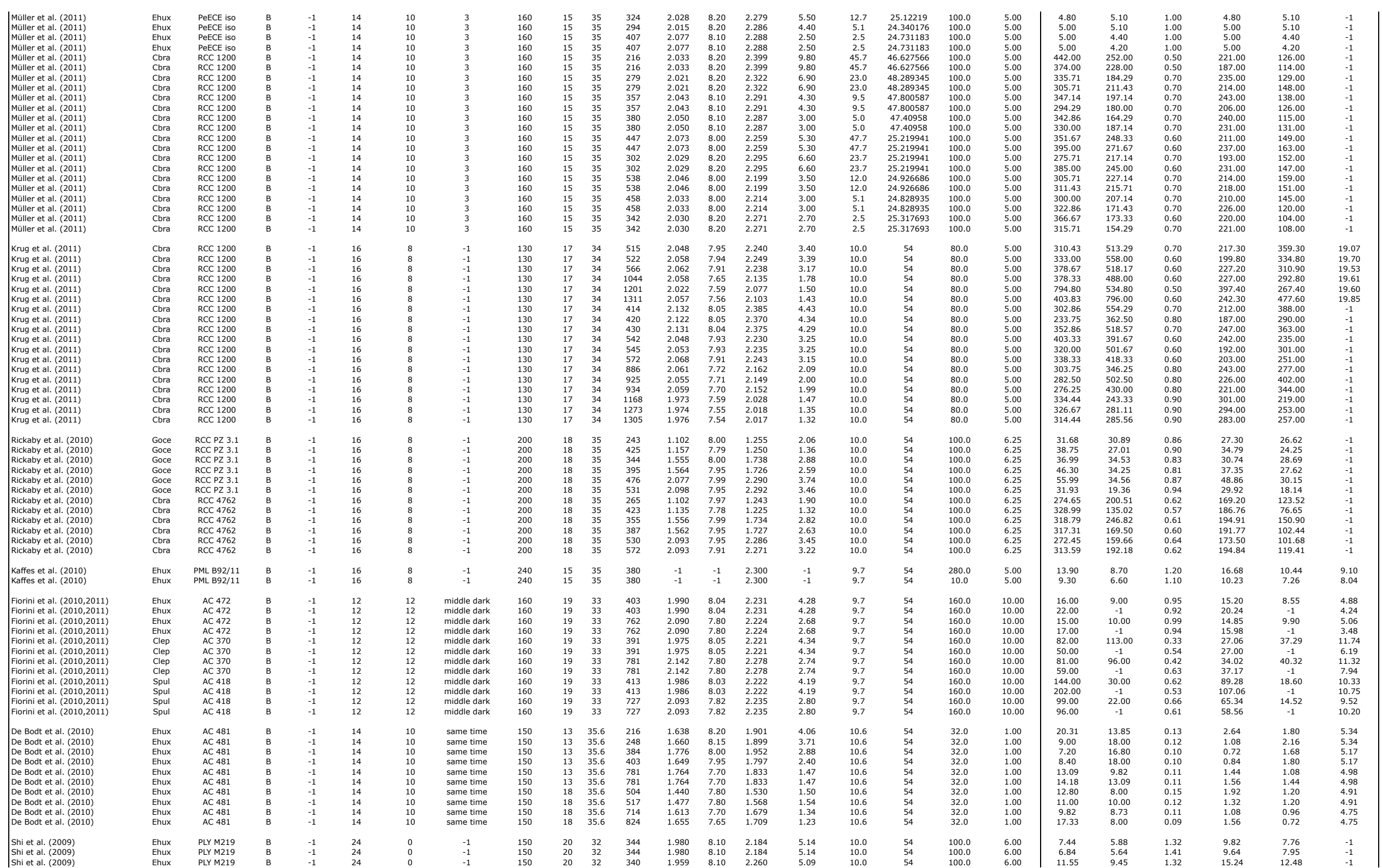




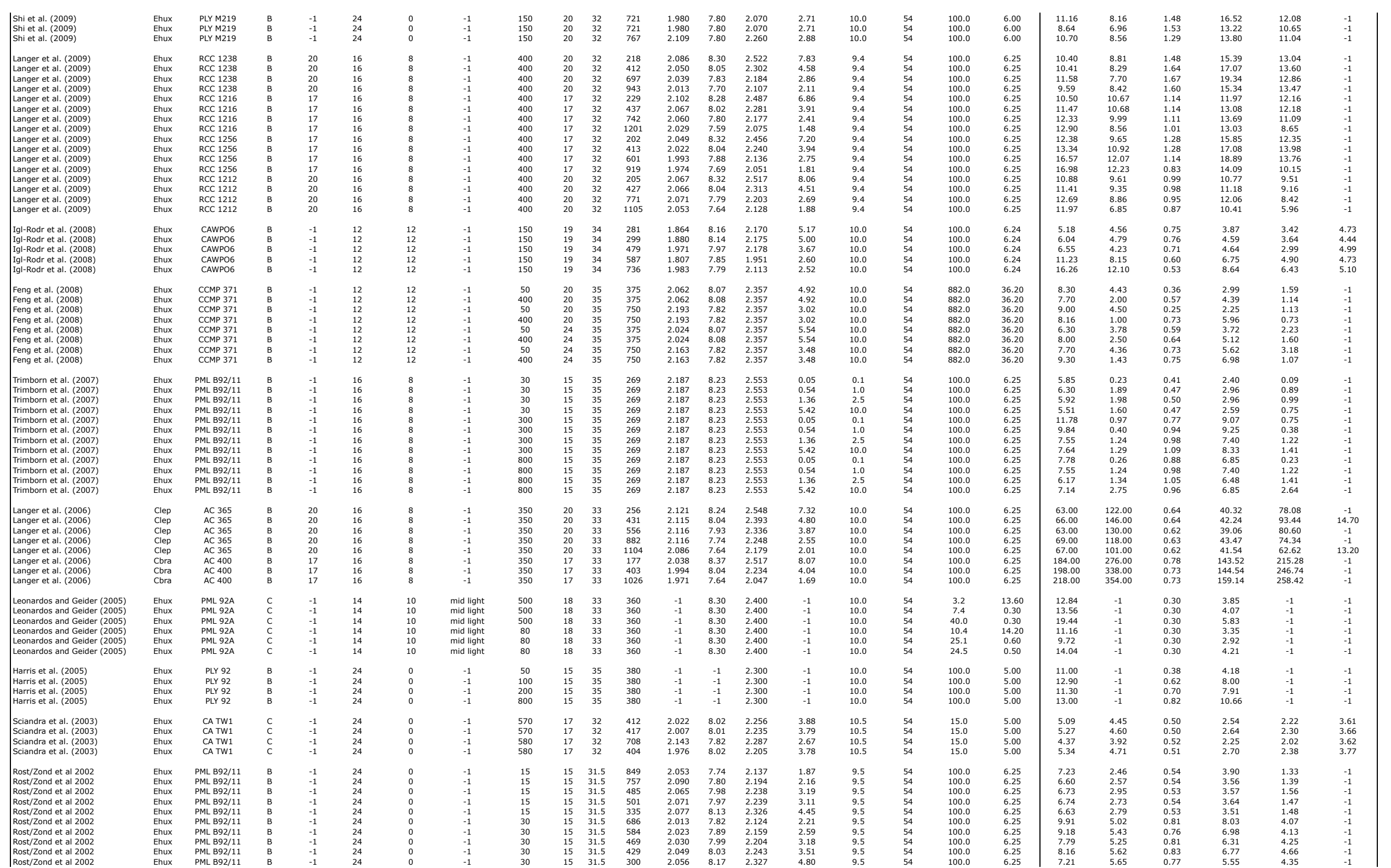




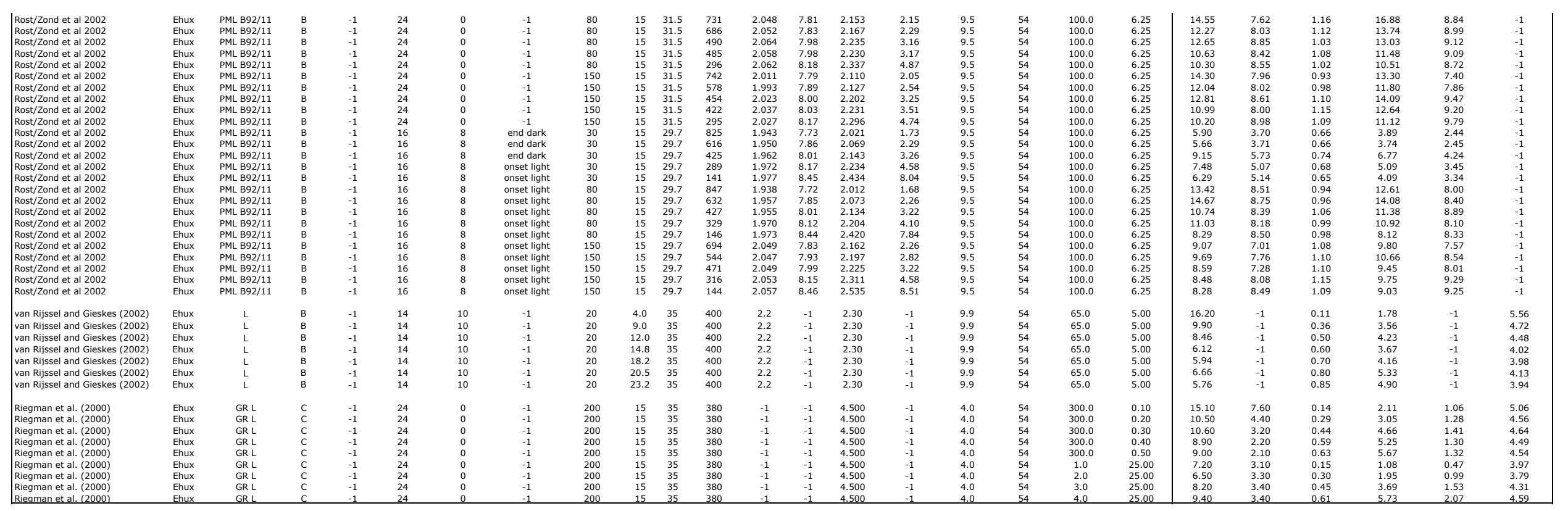

